\title{
Separation and Solidification of Rare Earth Nuclides from LiCl-KCl Based Eutectic Waste Salts using a series of Phosphorylation/Distillation/Solidification Processes
}

\author{
인산화/증류/고화의 일련공정을 이용한 $\mathrm{LiCl}-\mathrm{KCl}$ 공융염폐기물 내 \\ 희토류 핵종 분리 및 고화
}

Hee-Chul Eun*, Jung-Hoon Choi, In-Hak Cho, Hwan-Seo Park, and Geun-Il Park

Korea Atomic Energy Research Institute, 111 Daedeokdaero 989, Yuseong-gu, Daejeon, Korea

은희철*, 최정훈, 조인학, 박환서, 박근일

한국원자력연구원, 대전광역시 유성구 대덕대로 989 번길111

(Received October 7, 2013 / Revised November 28, 2013 / Approved December 2, 2013)

Pyroporcessing of spent nuclear fuel generates a considerable amount of $\mathrm{LiCl}-\mathrm{KCl}$ eutectic waste salt containing radioactive rare earth $(\mathrm{RE})$ chlorides. In this study, a series of processes, which consist of a phosphorylation/distillation process and a solidification process, were performed to minimize volume of the $\mathrm{LiCl}-\mathrm{KCl}$ eutectic waste salt and solidify a residual waste into a stable form at a relatively low temperature. Over $99 \mathrm{wt} \%$ of RE chlorides in $\mathrm{LiCl}-\mathrm{KCl}$ eutectic salt was converted and separated into $\mathrm{REPO}_{4}$ in the phosphorylation/distillation process using a mixture of $\mathrm{Li}_{3} \mathrm{PO}_{4}-\mathrm{K}_{3} \mathrm{PO}_{4}$. The separated $\mathrm{REPO}_{4}$ was solidified into a homogeneous and fine-grained form at $1,050^{\circ} \mathrm{C}$ using $\mathrm{LIP}($ Lead Iron Phosphate) as a solidification agent. The final waste volume was reduced below about $10 \%$ through the series of the processes.

Keywords: Pyroprocessing of spent nuclear fuel, $\mathrm{LiCl}-\mathrm{KCl}$ eutectic salt, Rare earth, Phosphorylation, Distillation, Solidification

사용후핵연료 파이로프로세싱에서 발생하는 $\mathrm{LiCl}-\mathrm{KCl}$ 공융염폐기물의 부피를 최소화하고 최종적으로 잔류하는 폐기물을 비교적 낮은 온도에서 안정한 형태로 고화하고자 희토류 핵종 염화물을 함유한 $\mathrm{LiCl}-\mathrm{KCl}$ 공융염을 이용하여 인산화/증류 및 세라믹 고화의 일련공정을 수행하였다. $\mathrm{LiCl}-\mathrm{KCl}$ 공융염 내 희토류 염화물은 혼합인산화제 $\left(\mathrm{Li}_{3} \mathrm{PO}-\mathrm{K}_{3} \mathrm{PO}_{4}\right)$ 를 이용한 인산화 및 공융염 감압증류공정을 통하여 $99 \%$ 이상을 인산화물 형태로 전환/분리할 수 있었고, 분리한 희토류 인산화물은 고화매 질로서 LIP(Lead Iron Phosphate)를 이용하여 $1,050^{\circ} \mathrm{C}$ 에서 균질하고 치밀한 형태의 고화체로 제조할 수 있었으며, 최종적으 로 발생하는 방사성 폐기물 부피를 10\% 이하로 감용할 수 있음을 확인하였다.

중심단어 : 사용후핵연료 파이로프로세싱, $\mathrm{LiCl}-\mathrm{KCl}$ 공융염, 희토류 핵종, 인산화, 증류, 세라믹 고화

*Corresponding Author.

Hee-Chul Eun, Korea Atomic Energy Research Institute, E-mail: ehc2004@kaeri.re.kr, Tel: +82.52.868.2712 
Hee-Chul Eun. et al : Separation and Solidification of Rare Earth Nuclides from LiCl-KCl Based Eutectic Waste Salts using a series of Phosphorylation/Distillation/Solidification Processes

\section{1.서 론}

혁신적인 핵연료주기를 위한 유망기술 중 하나로서 용 융염 내에서 전기화학적 방법을 이용하여 사용후핵연료로 부터 유용한 자원인 U과 TRU(transuranic) 금속을 회수하 는 파이로프로세싱(pyroprocessing)에서는 염화물 형태 의 희토류 핵종(rare earths)들을 함유하고 있는 $\mathrm{LiCl}-\mathrm{KCl}$ 공융염폐기물이 상당량 발생된다[1-4]. $\mathrm{LiCl}-\mathrm{KCl}$ 공융염폐 기물 내에 함유되어 있는 염화물 형태의 핵분열생성물은 높은 방사열과 방사능을 가지고 있어 이를 함유한 LiCl$\mathrm{KCl}$ 공융염폐기물은 고준위 방사성 폐기물로 분류될 수 있으며, 파이로프로세싱의 기술적 경쟁력을 높이기 위해 서는 이러한 방사성 폐기물의 부피를 최소화할 수 있고 최 종적으로 잔류하는 폐기물을 안정한 형태로 처리할 수 있 는 기술이 뒷받침되어야 한다[5].

$\mathrm{LiCl}-\mathrm{KCl}$ 공융염폐기물의 부피를 최소화하기 위해서는 $\mathrm{LiCl}-\mathrm{KCl}$ 공융염폐기물 내 희토류 핵종을 분리할 수 있는 핵종분리기술이 필요하고, 최종적으로 잔류하는 폐기물을 안정한 형태로 처리하기 위해서는 최종적으로 발생하는 폐기물에 대한 효과적인 고화체 제조기술이 필요하다. 현 재 공융염폐기물 내에서 희토류 핵종을 분리하기 위해 공 융염 내에 용해되어 있는 희토류 염화물을 불용성 화합물 인 산화물로의 전환을 목적으로 $\mathrm{Li}_{2} \mathrm{O}$ 와 $\mathrm{V}_{2} \mathrm{O}_{5}$ 와 같은 산화 침전제를 이용하는 방법들이 연구되었으나 용융염내 희토 류 염화물의 산화물로의 전환율이 높지 않고 공융염내 불 순물을 발생시켜 공융염의 조성이 변화됨으로써 공융염
의 재생이 쉽지 않게 된다는 단점을 가지고 있다[6,7]. 또 한 제올라이트를 이용하여 공융염폐기물 내 핵종을 분리 하고 최종처분을 위해 안정한 형태로 고화하는 기술이 연 구되었으나 이 또한 핵종분리효율이 높지 않으며, 최종적 으로 발생하는 폐기물양이 오히려 증가할 수 있는 문제점 을 보유하고 있다[5,8]. 이와 달리 염화물을 불용성 화합물 인 인산화물로 전환하는 방법은 공융염폐기물 내에서 희 토류 핵종을 분리하는데 매우 효과적인 것으로 보고되고 있다[1,9]. 특히 혼합 인산화제를 사용할 경우에는 공융염 의 조성을 변화시키지 않아 공융염 재생이 가능함이 확인 되었으며[8], 이와 같은 인산화 공정 후 감압증류공정을 적 용할 경우 희토류 인산화물과 $\mathrm{LiCl}-\mathrm{KCl}$ 공융염을 효과적으 로 분리할 수 있음이 파악되었다[10]. 이상의 공정들을 통 해 분리되는 희토류 인산화물은 분말형태이고, 이는 악티 나이드 고정화 광물로 많이 연구되고 있는 안정한 형태 중 하나이며[11,12], 방사성 폐기물로서 저장과 처분에 적합 한 고화체 형태로 제조하는 기술이 수반되어야 한다. 최근 의 연구에 따르면 이러한 희토류 핵종들과 유사한 방사성 핵종 화합물은 Synrock을 이용하여 고화체를 제조하고자 하였으며, 이를 위해서는 $1300^{\circ} \mathrm{C}$ 이상의 고온 및 고압의 소결조건을 조성해야 하는 어려움이 존재한다[13].

따라서 본 연구에서는 사용후핵연료 파이로프로세싱 에서 발생하는 $\mathrm{LiCl}-\mathrm{KCl}$ 공융염폐기물의 부피를 최소화하 고 최종적으로 잔류하는 폐기물을 비교적 낮은 온도에서 안정한 형태로 고화하고자 인산화/증류 및 세라믹 고화를 이용한 LiCl-KCl 공융염폐기물 내 핵종분리 및 고화기술을

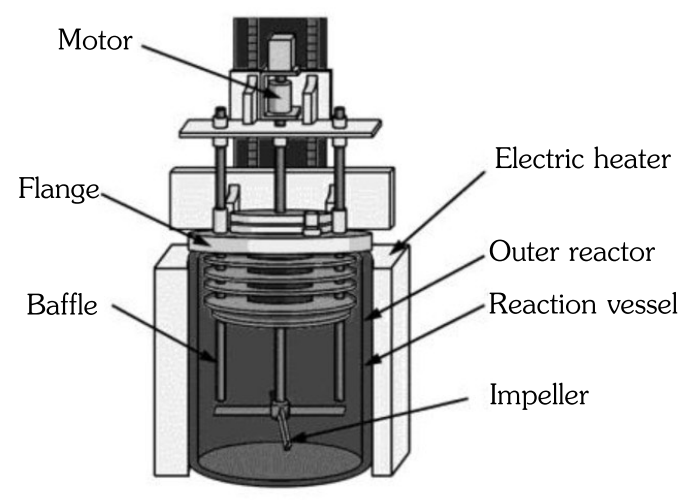

(a) For phosphorylation

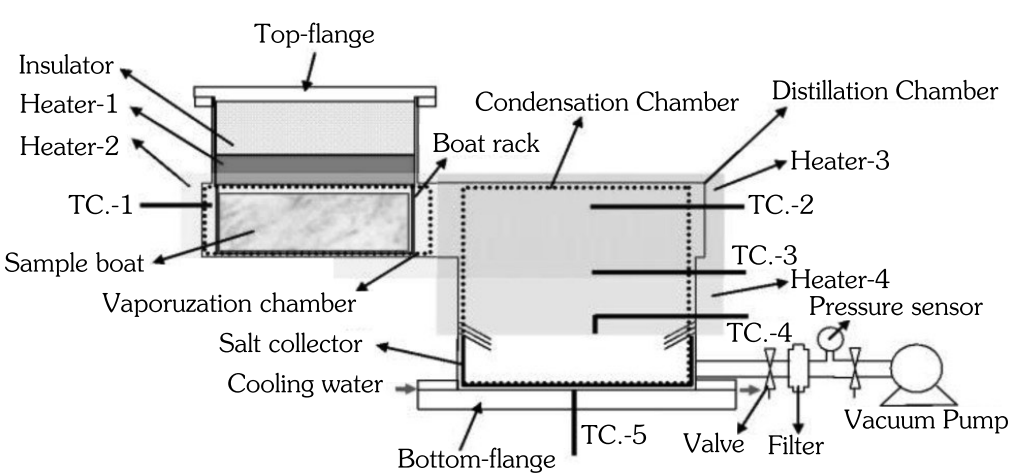

TC.: thermocouple

Fig. 1. A schematic diagram of the experimental apparatus for separation of rare earth nuclides in $\mathrm{LiCl}-\mathrm{KCl}$ eutectic waste salts. 
Hee-Chul Eun. et al : Separation and Solidification of Rare Earth Nuclides from LiCl-KCl Based Eutectic Waste Salts using a series of Phosphorylation/Distillation/Solidification Processes

Table 1. Operation conditions for vacuum distillation of $\mathrm{LiCl}-\mathrm{KCl}$ eutectic salt containing rare earth phosphates

\begin{tabular}{ccccc}
\hline Heater-1, $2\left({ }^{\circ} \mathrm{C}\right)$ & Heater-3 $\left({ }^{\circ} \mathrm{C}\right)$ & Heater-4 $\left({ }^{\circ} \mathrm{C}\right)$ & $\begin{array}{c}\text { Operating time at a } \\
\text { set temp. }(\mathrm{h})\end{array}$ \\
\hline 960 & 700 & 600 & $0.005 \sim 50$ & 2.0 \\
\hline
\end{tabular}

제시하고자 하였으며, 이를 위해 희토류 핵종 염화물을 함 유한 $\mathrm{LiCl}-\mathrm{KCl}$ 공융염을 이용하여 인산화/증류 및 세라믹 고화의 일련공정을 수행함으로써 핵종분리특성 및 고화체 제조특성을 평가하였다.

\section{2. 실험장치 및 방법}

\section{1 인산화/증류}

본 연구에서 $\mathrm{LiCl}-\mathrm{KCl}$ 공융염 내 희토류 핵종 분리를 위 해 사용한 인산화/증류장치는 인산화장치와 감압증류장 치로 구성되며, 그 개략도를 Fig. 1에 나타내었다[9,14]. 인 산화장치(Fig. 1(a))는 교반기, 전기모터, 플랜지, 반응기, 반응용기, 전기히터 등으로 구성되어 있다. 인산화제를 이 용한 공융염 내 희토류 염화물의 인산화는 고체-액체반응 으로 고체-액체의 균일혼합이 반응효율에 큰 영향을 미칠 수 있으며, 고체-액체 균일혼합을 통해 교반효과를 증진 시키고자 네 개의 경사형 블레이드를 가지는 임펠러와 배 플(baffle)로 구성한 교반기를 적용하였다. 감압증류장치 (Fig. 1(b))는 휘발된 공융염을 대부분 회수하는데 초점을 맞추어 공융염 증기가 한 위치에서만 응축될 수 있도록 휘 발챔버와 응축챔버를 연결관 없이 하나의 형태로 제작되 었고, 챔버 내 응축염이 회수용기 바닥에서만 냉각면이 존 재하도록 설계하였다. 이 장치는 각각 독립적으로 제어할 수 있는 네 개의 전기히터가 설치되어 있다는 것과 닫힌 계 에서 운전을 할 수 있다는 것이 가장 큰 특징이다.

인산화/증류실험은 2,000 g의 LiCl-KCl 공융염(Alfa Aesar, $99 \%, \mathrm{LiCl}$ 몰비: 0.59)과 8가지의 희토류 핵종(La, Y, Ce, $\mathrm{Pr}, \mathrm{Nd}, \mathrm{Sm}, \mathrm{Eu}, \mathrm{Gd}$ ) 염화물(공융염의 $5 \mathrm{wt} \%: 100 \mathrm{~g}$ )을 함유한 모의 공융염 시료를 이용하여 수행하였으며, 세부 운전방법은 다음과 같다. 먼저, 희토류 핵종 염화물을 함 유한 공융염 시료를 반응용기에 담고 인산화 장치 내부 로 장입하여 $450^{\circ} \mathrm{C}$ 로 가열한 후 시료가 용융되었을 때 희
토류 염화물의 당량비의 혼합인산화제 $\left(\mathrm{Li}_{3} \mathrm{PO}_{4}-\mathrm{K}_{3} \mathrm{PO}_{4}, 65\right.$ $\mathrm{g}, \mathrm{Li}_{3} \mathrm{PO}_{4}$ 몰비: $0.59, \mathrm{Li}_{3} \mathrm{PO}_{4}$ 순도: $99.99 \%, \mathrm{~K}_{3} \mathrm{PO}_{4}$ 순도: 99\%)를 주입하고 $300 \mathrm{rpm}$ 의 속도로 용융된 시료를 30 분 동안 교반한 후 실온으로 냉각하여 반응용기에서 공융염 시료를 회수한다. 공융염 내에서 희토류 염화물을 30 분 동안 인산화하는 과정 중 일정시간 $(0,5,10,20,30$ 분 $)$ 에 따라 석 영관을 이용하여 공융염 시료를 분취하고 고체상 으로 냉각한 후 $0.1 \mathrm{M}$ 의 질산용액에 용해하여 필터가 부 착된 주사기로 용액시료를 채취하였으며, $\mathrm{ICP}$ 를 이용하 여 채취한 용액 내 희토류 원소의 농도를 분석하여 일정시 간에 따른 희토류 염화물의 인산화효율을 산출하였다. 희 토류 인산화 반응 후 반응용기에서 회수한 공융염 시료는 감압증류장치의 휘발용기 내에 담기 위해 $5 \mathrm{~cm}$ 이하의 크 기로 파쇄하고, 공융염 시료를 담은 휘발용기를 감압증류 장치 내에 장입하여 Table 1 에 나타낸 조건으로 운전하여 $\mathrm{LiCl}-\mathrm{KCl}$ 공융염과 희토류 인산화물을 분리한다.

\section{2 고화}

인산화/증류장치에서 발생된 잔류폐기물(희토류 인산 화물)의 고화실험은 내부온도 기준으로 $1,450^{\circ} \mathrm{C}$ 까지 가열 이 가능하고 비활성 분위기를 유지할 수 있는 고온전기로 에서 수행하였다.

희토류 인산화물의 고화를 위해 사용된 고화매질은 고화 체 제조를 위한 운전온도를 낮추기 위해 비교적 낮은 온 도에서 제조가 가능한 $\operatorname{LIP}\left(\right.$ 용융온도: $950 \sim 1150^{\circ} \mathrm{C}$ )로 결 정하였고[14], 다음과 같은 절차를 거쳐 준비하였다. 먼저 $\mathrm{NH}_{4} \mathrm{H}_{2} \mathrm{PO}_{4}, \mathrm{PbO}$, 및 $\mathrm{Fe}_{2} \mathrm{O}_{3}$ 를 혼합하여 용기에 담고, 암모 늄 성분을 휘발시키기 위해 $500{ }^{\circ} \mathrm{C}$ 에서 2 시간 유지하며, $1,000^{\circ} \mathrm{C}$ 에서 4 시간동안 소결한다. 이러한 과정을 통해 얻 은 고화매질은 $\mathrm{PbO}, \mathrm{P}_{2} \mathrm{O}_{5}$ 및 $\mathrm{Fe}_{2} \mathrm{O}_{3}$ 로 구성되었으며, 조성 은 Table 2에 나타내었다.

$\mathrm{LIP}$ 를 이용한 희토류 인산화물의 고화체 제조는 그라 파이트 용기(직경: $40 \mathrm{~mm}$, 높이 $50 \mathrm{~mm}$ )를 사용하여 용 
Hee-Chul Eun. et al : Separation and Solidification of Rare Earth Nuclides from LiCl-KCl Based Eutectic Waste Salts using a series of Phosphorylation/Distillation/Solidification Processes

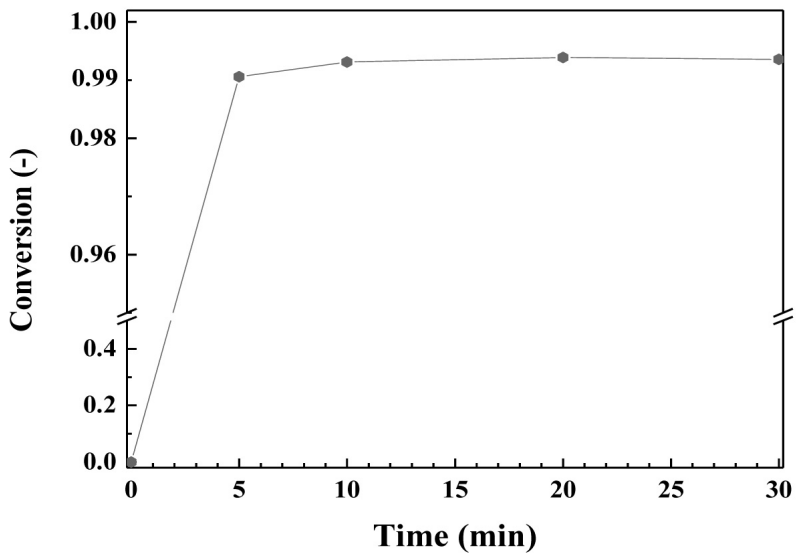

Fig. 2. Total conversion ratios of rare earth chlorides into a phosphate form in $\mathrm{LiCl}-\mathrm{KCl}$ eutectic salt (temperature: $450^{\circ} \mathrm{C}$, stirring rate: $300 \mathrm{rpm}$, phosphorylation agent: 1 eq.).

(a) Insoluble materials after phosphorylation

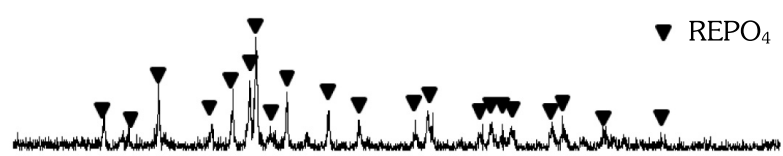

(b) Residues after distillation

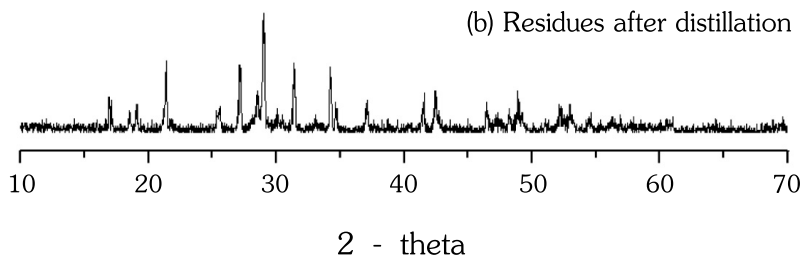

Fig. 3. XRD patterns of products obtained from phosphorylation and distillation processes (RE: rare earth).

기와 고화체의 분리가 용이하도록 하였고, 이전의 연구에 서 수행하였던 희토류 산화물 고화체 제조조건을 고려하 여 희토류 인산화물의 함량을 $40 \mathrm{wt} \%$ 로 선정하여 약 $50 \mathrm{~g}$ 의 고화체를 제조하였으며, LIP와 희토류 인산화물에 대 한 소량의 고화시험을 통해 제조된 고화체들 중 비교적으 로 공극이 적고 균질한 형태를 보인 고화체의 제조조건의 온도인 $1,050^{\circ} \mathrm{C}$ 와 4 시간의 유지시간을 고화조건으로 결 정하였다.

\section{3. 실험결과 및 고찰}

Table 2. Compositions of LIP used in this study

\begin{tabular}{cccc}
\hline Compounds & $\mathrm{PbO}$ & $\mathrm{P}_{2} \mathrm{O}_{5}$ & $\mathrm{Fe}_{2} \mathrm{O}_{3}$ \\
\hline $\begin{array}{c}\text { Contents } \\
(\mathrm{wt} \%)\end{array}$ & 54.0 & 34.0 & 12.0 \\
\hline
\end{tabular}

\section{1 희토류 염화물 인산화/분리}

혼합 인산화제 $\left(\mathrm{Li}_{3} \mathrm{PO}_{4}-\mathrm{K}_{3} \mathrm{PO}_{4}\right)$ 를 이용한 $\mathrm{LiCl}-\mathrm{KCl}$ 공융염 내 희토류 염화물의 인산화에 대한 전환율을 혼합 인산화 제를 투입하기 전 공융염 내 희토류 핵종들의 총 농도와 일 정시간이 경과한 후 공융염 내 희토류 핵종들의 총 농도를 이용하여 계산하였으며, 그 결과를 Fig. 2에 나타내었다. Fig. 2에서 보는 바와 같이 혼합 인산화제를 이용한 희토 류 염화물의 인산화는 약 10 분 후 종료되었고, 이를 통해 공융염 내 희토류 염화물의 인산화는 짧은 시간에서 효과 적으로 희토류 염화물을 공융염 내 불용성 화합물인 희토 류 인산화물로 전환할 수 있음을 알 수 있었으며, 이 결과 는 이전의 연구결과와 유사함을 확인할 수 있었다[14]. 인 산화를 통해 발생된 불용성 화합물의 인산화되었음을 확 인하기 위해 불용성 화합물에 대한 X선 회절분석을 수행하 였고, 그 결과를 Fig. 3(a)에 나타내다. Fig. 3(a)에 따르면, 불용성 화합물은 거의 대부분이 인산화물로 전환되었음을 확인할 수 있었고, 미반응의 인산화제는 공융염 내 불용성 인 $\mathrm{Li}_{3} \mathrm{PO}_{4}$ 로 전환되어 존재할 것으로 판단되나 미량으로 X 선 회절분석에서는 확인되지 않았다.

희토류 염화물의 인산화 후 발생된 고체상의 $\mathrm{LiCl}-\mathrm{KCl}$ 공융염에서 희토류 인산화물을 분리하기 위한 희토류 인 산화물 함유 공융염의 감압증류 실험결과는 Table 3에 나 타내었다. 이론적으로 계산할 때 희토류 염화물 $($ 약 $100 \mathrm{~g})$ 이 모두 인산화물로 전환되었을 경우 발생되는 인산화물 의 양은 약 $95 \mathrm{~g}$ 이다. 그러나 감압증류 후 발생되는 희토 류 인산화물은 약 $96.7 \mathrm{~g}$ 이고, 이는 이론적인 계산보다 많 은 값으로 감압증류과정에서 금속재질(Inconel 625)로 제 작된 휘발용기가 고온에서 공융염과의 반응으로 인해 부 식된 금속 $(\mathrm{Ni}$ or $\mathrm{Cr}$ or $\mathrm{Fe}$ )들이 소량 발생된 것에서 기인된 것으로 판단되며, 거의 대부분의 희토류 염화물이 인산화 와 감압증류를 통해 인산화물 형태로 분리된 것으로 사료 된다. 이는 감압증류를 통해 회수된 공융염 내 희토류 농 도를 분석한 결과에서 확인되었으며, 회수된 공융염 내 희 
Hee-Chul Eun. et al : Separation and Solidification of Rare Earth Nuclides from LiCl-KCl Based Eutectic Waste Salts using a series of Phosphorylation/Distillation/Solidification Processes

Table 3. Experimental results of vacuum distillation of $\mathrm{LiCl}-\mathrm{KCl}$ eutectic salt containing rare earth phosphates

\begin{tabular}{ccccc}
\hline $\begin{array}{c}\text { Sample } \\
\text { (salt + rare earth } \\
\text { phosphates }) \\
(\mathrm{g})\end{array}$ & $\begin{array}{c}\text { Rare earth } \\
\text { phosphates } \\
(\mathrm{g})\end{array}$ & $\begin{array}{c}\text { Salt collection } \\
(\mathrm{g})\end{array}$ & $\begin{array}{c}\text { RE separation } \\
(\mathrm{wt} \%)\end{array}$ & $\begin{array}{c}\text { Salt recovery } \\
(\mathrm{wt} \%)\end{array}$ \\
\hline 2136.6 & 96.7 & 2031.3 & $>99.9 \mathrm{wt} \%$ & 99.6 \\
\hline
\end{tabular}

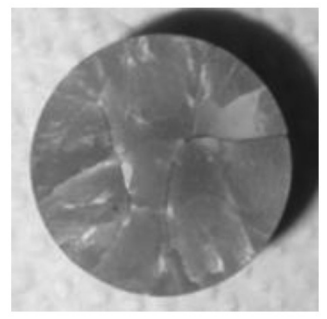

(a) LIP $100 w t \%$

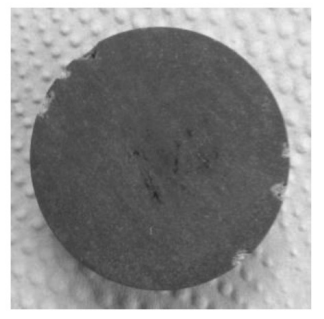

(b) $\mathrm{LIP} 60 \mathrm{wt} \%+\mathrm{RE}$ phosphate $40 \mathrm{wt} \%$
Fig. 4. Photos of products obtained from the solidification process using LIP.

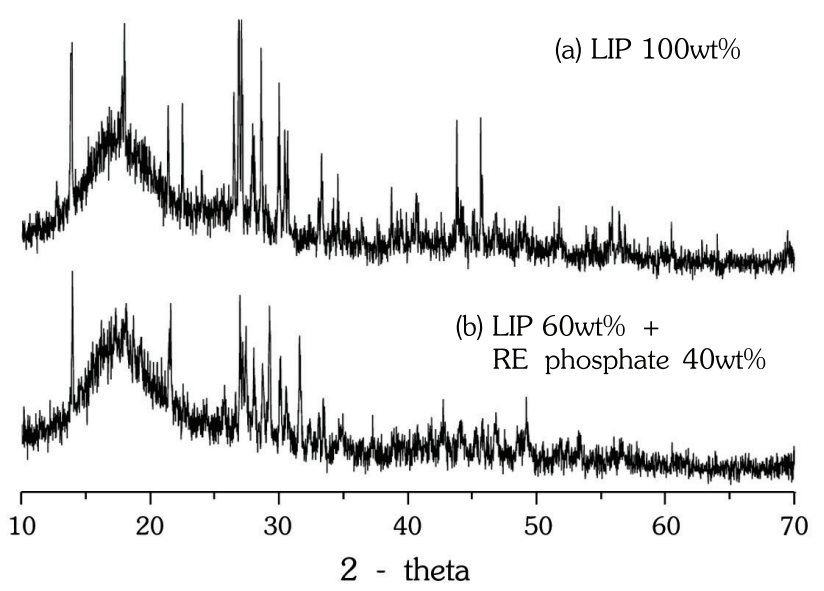

Fig. 5. XRD-patterns of products obtained from the solidification process using LIP.

토류 핵종들의 총 함량이 약 $0.002 \mathrm{~g}$ 으로 인산화/증류를 통한 $\mathrm{LiCl}-\mathrm{KCl}$ 공융염 내 희토류 핵종 분리효율은 약 99.9 $\mathrm{wt} \%$ 까지 얻을 수 있음을 알 수 있었다. 또한 회수된 공융 염의 양은 초기에 주입한 공융염의 양 $(2,000 \mathrm{~g})$ 보다 높은 값(2136.6 g)을 보이고 있는데 이는 혼합인산화제를 이용 한 희토류 염화물의 인산화 과정에서 $\mathrm{LiCl}$ 또는 $\mathrm{KCl}$ 이 발 생된 것에 기인된 것으로 파악된다[14]. 감압증류과정에서
$\mathrm{LiCl}-\mathrm{KCl}$ 공융염 내 희토류 인산화물의 화학적 형태 변화 를 살펴보기 위해 Fig. 3(b)에 나타낸 것과 같이 X선 회절 분석을 실시하였으며, 그 결과 감압증류과정에서 희토류 인산화물의 화학적 형태는 변화되지 않음을 확인할 수 있 었다. 또한 인산화/증류를 통해 $99 \mathrm{wt} \%$ 이상의 $\mathrm{LiCl}-\mathrm{KCl}$ 공 융염을 정제된(희토류 핵종 농도 $<1 \mathrm{ppm}$ ) 형태로 회수할 수 있었으며, 이 정제된 공융염은 파이로프로세싱에서 재 사용이 가능할 것으로 사료된다.

\section{2 희토류 인산화물 고화}

희토류 인산화/증류를 통해 얻어진 희토류 인산화물 과 고화매질 LIP를 이용하여 2.2에서 나타낸 고화조건에 서 희토류 인산화물 고화체를 제조하였으며, 같은 고화조 건에서 고화매 LIP만을 이용한 고화체를 제조하여 Fig. 4 와 같이 외형을 비교하고자 하였다. Fig. 4 를 볼 때 고화매 질만 있는 경우에는 내부에 크랙(crack)이 존재하여 불안 정한 형태의 고화체를 형성하는 것으로 판단되나 희토류 인산화물이 $40 \mathrm{wt} \%$ 로 존재하는 고화체는 크랙(crack)이 존 재하지 않고 고화매질만 존재하는 경우의 고화체보다 훨 씬 더 견고한 것으로 보인다. 또한 고화매질만으로 구성 된 고화체의 경우는 연한 보라색으로 유리고화체와 유사 한 외형을 보유하고 있으나 희토류 인산화물을 함유한 고 화체는 진한 청록색을 띠며, 외형적으로는 결정질 고화체 의 형상을 보였다.

고화체의 구조적 형상을 파악하기 위해 상기의 고화체 에 대한 X선 회절분석을 실시하였으며, 그 결과를 Fig. 5에 나타내었다. Fig. 5에 따르면 고화매질만으로 구성된 고화 체와 희토류 인산화물을 함유한 고화체의 회절구조가 거 의 일치함을 알 수 있고, 고화매질 LIP를 이용한 고화체는 유리질과 결정질을 함께 함유한 형태인 것으로 보이며, 이 전의 연구에서도 고화매질 LIP가 이와 같은 형태를 보유하 고 있음을 확인할 수 있었다[15]. 또한, 희토류 인산화물을 
Hee-Chul Eun. et al : Separation and Solidification of Rare Earth Nuclides from LiCl-KCl Based Eutectic Waste Salts using a series of Phosphorylation/Distillation/Solidification Processes

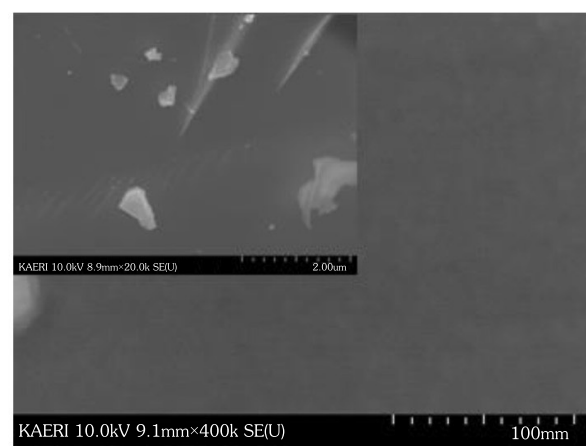

(a) LIP $100 w t \%$

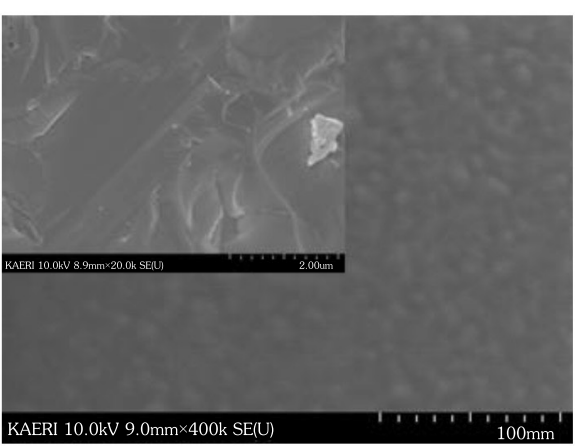

(b) LIP $60 \mathrm{wt} \%+\mathrm{RE}$ phosphate $40 \mathrm{wt} \%$

Fig. 6. SEM images of products obtained from the solidification process using LIP.

함유한 고화체의 X선 회절분석자료에서 희토류 인산화물 의 결정피크가 나타나지 않았으며, 이를 통해 희토류 인산 화물이 LIP 고화체 내에서 결정을 이루지 못하고 유리매질 과 함께 혼화된 것으로 사료된다.

고화제의 균질성을 파악하기 위해 고화체 절단면에 대 한 표면분석을 실시하였으며, 그 결과를 Fig. 6 에 나타내었 다. Fig. 6에서 볼 수 있듯이 고화매질만 존재하는 고화체 와 희토류 인산화물이 존재하는 고화체 모두 공극(pore) 이 없는 치밀한 형태로 형성되었음을 알 수 있으며, 희토 류 인산물을 함유한 고화체의 경우 상분리가 없이 균질한 형태를 보유하고 있음을 확인할 수 있었다. 이전의 연구에 서 희토류 산화물을 인산화물로 전환한 후 zinc titanate가 주요성분인 고화매질을 이용하여 제조한 고화체는 다수의 공극이 존재하고 상분리가 되어 있음이 확인되었으나 본 연구에서 제조한 LIP 고화매질의 희토류 인산화물 고화체 는 공극이 거의 없고 상분리가 존재하지 않아 이전의 연구 에서 제조된 고화체와 비교할 때 치밀성과 균질성이 크게 향상된 것으로 파악된다[13]. 이상의 결과를 종합해 볼 때 고화매질 LIP를 이용하여 견고하고 균질한 형태의 희토류 인산화물 고화체 제조를 제조할 수 있을 것으로 판단된다.

\section{3 핵종분리/고화 일련공정기술의 효용성}

혼합 인산화제를 이용한 희토류 염화물의 인산화와 $\mathrm{LiCl}-\mathrm{KCl}$ 공융염 감압증류를 통한 희토류 핵종 분리 및 LIP 고화매질을 이용한 희토류 인산화물 고화의 일련공정을 통한 희토류 염화물 함유 $\mathrm{LiCl}-\mathrm{KCl}$ 공융염폐기물 처리기
술의 효용성을 평가하기 위해 본 연구에서 사용된 희토류 함유 $\mathrm{LiCl}-\mathrm{KCl}$ 공융염 시료와 최종 발생 고화체를 기준으 로 폐기물 부피 감용효과를 살펴보았다. 감용효과를 살펴 보기에 앞서 고화매질 LIP를 이용한 희토류 인산화물 고화 체의 밀도를 측정하였고, 그 결과 약 $4.1 \mathrm{~g} / \mathrm{cm}^{3}$ 인 것으로 확인되었다. 이는 zinc titanate가 주요성분인 고화매질을 이용하여 제조한 고화체(밀도: $3.6 \mathrm{~g} / \mathrm{cm}^{3}$ )보다 우수한 치 밀성을 가지고 있음을 다시 확인할 수 있는 것이며[13], 이 결과는 희토류 인산화물의 함량 즉 폐기물 함유율(waste loading)이 기존의 연구보다 높은 것과 깊은 연관이 있는 것으로 판단된다. 본 연구에서 시료로 사용된 희토류를 함 유한 공융염(밀도: 약 $2.0 \mathrm{~g} / \mathrm{cm}^{3}$ )의 부피는 약 $1,050 \mathrm{~cm}^{3}$ 이 었고, 최종적으로 발생되는 희토류 인산화물 고화체의 부 피는 약 $61 \mathrm{~cm}^{3}$ 였으며, 이 값들을 고려해 볼 때 인산화/증 류를 이용한 핵종분리와 LIP 고화매질을 이용한 희토류 인 산화물 고화의 일련공정을 통해 $\mathrm{LiCl}-\mathrm{KCl}$ 공융염폐기물의 부피를 $10 \%$ 이하로 감소시킬 수 있어 사용후핵연료 파이 로프로세싱에서 발생되는 $\mathrm{LiCl}-\mathrm{KCl}$ 공융염폐기물을 효과 적으로 처리하기 위한 공정기술로서 인산화/증류 및 고화 의 일련공정을 적용할 수 있으리라 사료된다.

\section{4. 결론}

사용후핵연료 파이로프로세싱에서 발생하는 LiCl-KCl 공융염폐기물의 부피를 최소화하고 최종적으로 잔류하는 폐기물을 비교적 낮은 온도에서 안정한 형태로 고화하고 자 희토류 핵종 염화물을 함유한 $\mathrm{LiCl}-\mathrm{KCl}$ 공융염을 이용 
Hee-Chul Eun. et al : Separation and Solidification of Rare Earth Nuclides from LiCl-KCl Based Eutectic Waste Salts using a series of Phosphorylation/Distillation/Solidification Processes

하여 인산화/증류 및 세라믹 고화의 일련공정을 수행하 였다. LiCl-KCl 공융염 내 희토류 염화물은 혼합인산화제 $\left(\mathrm{Li}_{3} \mathrm{PO}_{4}-\mathrm{K}_{3} \mathrm{PO}_{4}\right)$ 를 이용한 인산화 및 공융염 감압증류를 통 해 99wt\% 이상을 인산화물 형태로 분리할 수 있었고, 고화 매질로서 LIP(Lead Iron Phosphate)를 이용한 희토류 인 산화물 고화를 통해 치밀하고 균질한 고화체를 제조할 수 있었으며, 상기의 일련공정을 통해 최종적으로 발생하는 방사성 폐기물 부피를 $10 \%$ 이하로 감용할 수 있었다. 따라 서 상기의 일련공정을 적용하여 $\mathrm{LiCl}-\mathrm{KCl}$ 공융염폐기물을 효과적으로 처리할 수 있을 것으로 판단되며, 상기의 일련 공정을 통한 $\mathrm{LiCl}-\mathrm{KCl}$ 공융염폐기물 처리기술을 정립하기 위해 추후연구로서 고화체 침출실험을 통한 고화체의 건 전성 평가가 수반되어야 할 것으로 판단된다.

\section{감사의 글}

이 논문은 2013년도 정부(미래과학창조부)의 재원으 로 한국연구재단의 지원을 받아 수행된 연구임(원자력기 술개발사업, 2012M2A8A5025801)

\section{REFERENCES}

[1] V. A. Volkovich, T.R. Griffiths, and R.C. Thied, "Treatment of molten salt wastes by phosphate precipitation removal of fission product elements after pyrochemical reprocessing of spent nuclear fuels in chloride melts", J. Nucl. Mater. 323, pp. 49-56 (2003).

[2] M. Matsumiya and H. Matsuura, "Pyrochemical process for electrochemically base metals in molten halides combined countercurrent eletromigration and electrowinning methods", J. Electroanal. Chem., 579, pp. 329-336 (2005).

[3] Y. J. Cho, H. C. Yang, H. C. Eun, E. H. Kim, and I. T. Kim, "Characteristics of oxidation reaction of rare earth chlorides for precipitation in $\mathrm{LiCl}-\mathrm{KCl}$ molten salt by oxygen sparging”, J. Nucl. Sci. Technol., 43(10), pp. 1280-1286 (2006).

[4] H.S. Lee, G.I. Park, K.H. Kang, J.M. Hur, J.G. Kim, D.H. Ahn, Y.Z. Cho, and E.H. Kim, "Pyroprocess- ing technology development at KAERI", Nucl. Eng. Technol., 43, pp. 317-328 (2011).

[5] M.T. Harrison, H.E. Simms, A. Jackson, and R.G. Lewin, "Salt waste treatment from a $\mathrm{LiCl}-\mathrm{KCl}$ based pyrochemical spent fuel treatment process", Radiochim. Acta, 96, pp. 295-301 (2008).

[6] Y. Katayama, R. Hagiwara, and Y. Ito, "Precipitation of rare earth compounds in $\mathrm{LiCl}-\mathrm{KCl}$ eutectic," J. Electrochem. Soc., 142, pp. 2174-2178 (1995).

[7] D. M. Smith, M. P. Neu, E. Garcia, and V. R. Dole, "Reaction chemistry of plutonium with vanadium pentoxide in molten salts," J. Alloys Compounds, 319, pp. 258-265 (2001).

[8] M.F. Simpson and P. Sachdev, "Development of electrorefiner waste salt disposal process for the EBR-II spent fuel treatment project", Nucl. Eng. Technol., 40, pp. 175-182 (2008).

[9] Y.Z. Cho, T.K. Lee, H.C. Eun, J.H. Choi, I.T. Kim, and G.I. Park, "Purification of used eutectic ( $\mathrm{LiCl}-$ $\mathrm{KCl})$ salt electrolyte from pyroprocessing", J. Nucl. Mater., 437, pp. 47-54 (2013).

[10] H.C. Eun, Y.Z. Cho, S.M. Son, T.K. Lee, H.C. Yang, I.T. Kim, and H.S. Lee, "Recycling of LiCl$\mathrm{KCl}$ eutectic based salt wastes containing radioactive rare earth oxychlorides or oxides", J. Nucl. Mater., 420, pp. 548-553 (2012).

[11] F. Poitrasson, E. Olekers, J. Schott, and J.M. Montel, "Experimental determination of synthetic $\mathrm{NdPO} 4$ monazite en-member solubility in water from $21^{\circ} \mathrm{C}$ to $300^{\circ} \mathrm{C}$ : Imbrications of rare earth element mobility in crustal fluids", Geochemica et Cosmochimica Acta, 40(10), pp. 2207-2221 (2004).

[12] L. Bois, M.J. Guittet, F. Carrot, P. Trocellier, and M. Gautier-Soyer, "Preliminary results on the leathing process of phosphate ceramics potential hosts for actinide immobilization", J. Nucl. Mater., 297, pp. 129-137 (2001).

[13] B.G. Ahn, H.S. Park, H.Y. Kim, H.S. Lee, and I.T. Kim, "Immobilization of radioactive rare earth oxide waste by solid phase sintering", J. Korean 
Hee-Chul Eun. et al : Separation and Solidification of Rare Earth Nuclides from LiCl-KCl Based Eutectic Waste Salts using a series of Phosphorylation/Distillation/Solidification Processes

Radioact. Waste Soc., 8(1), pp. 49-56 (2010).

[14] H.C. Eun, J.H. Kim, Y.Z. Cho, J.H. Choi, T.K. Lee, H.S. Park, and G.I. Park, "An optimal method for phosphorylation of rare earth chlorides in $\mathrm{LiCl}-\mathrm{KCl}$ eutectic based waste salt", J. Nucl. Mater., 442, pp. 175-178 (2013).

[15] S.T. Reis, M. Karabulut, and D.E. Day, "Structural features and properties of lead-ion-phosphate nuclear wasteforms", J. Nucl. Mater., 304, pp. 87-95 (2002). 